\title{
PANDEMI COVID-19 DAN ERA TATANAN KEBIASAAN BARU DALAM PERSPEKTIF PSIKOLOGI PARIWISATA
}

\author{
Ni Desak Made Santi Diwyarthi \\ Program Studi Administrasi Perhotelan, Politeknik Pariwisata Bali \\ Jalan Raya Darmawangsa, Kampial, Nusa Dua Bali \\ santidiwyarthi@yahoo.com
}

\begin{tabular}{l|l|l} 
Received: August, 2021 & Accepted: August, 2021 & Published: September, 2021 \\
\hline
\end{tabular}

\begin{abstract}
The COVID-19 Pandemic has had a major impact on human life and the world of tourism. The development of tourism has undergone major changes with the implementation of health protocol standards. This paper provides additional horizons of information regarding the COVID-19 pandemic and the new order of life, the New Normal Era, in the world of tourism. Since the pandemic has changed society's habits, and life has become a new norm. This study uses qualitative research methods with literature studies on the psychological situation of tourism conditions that occur, especially in Bali. The COVID-19 pandemic raises awareness of the importance of hygiene, health, and safety for the community. Hotel management obtained a certificate for cleanliness, health, safety, and environmental implementation. There are some local wisdoms, such as Sagilik Saguluk, Briuk Sapanggul, Briuk Sapanggul, Tri Hita Karana, and Desa Kala Patra, in society. The conclusion of this research is that the COVID-19 Pandemic has made the tourism world slump. It has to follow the strict health protocol standards as a New Normal Era.
\end{abstract}

Keywords: Covid-19 Pandemic, New Normal Era, Psychology of Tourism

\begin{abstract}
Abstrak
Pandemi Covid-19 berdampak besar terhadap kehidupan manusia, juga dunia pariwisata. Perkembangan pariwisata mengalami perubahan besar dengan diterapkannya standar protocol kesehatan. Tulisan ini memberikan tambahan cakrawala informasi mengenai pandemi Covid-19 dan tatanan kehidupan baru di dalam dunia pariwisata. Penelitian ini bertujuan menelaah perkembangan pariwisata ditinjau berdasar pandangan Psikologi, terutama dalam situasi Pandemi Covid-19, yang terjadi pada era tatanan kebiasaan baru. Penelitian ini menggunakan metode penelitian kualitatif dengan studi literatur terhadap situasi psikologis kondisi pariwisata yang terjadi, khususnya di Bali. Kesimpulan dari penelitian ini adalah bahwa pandemi Covid-19 telah membuat dunia pariwisata terpuruk dan berada dalam era tatanan kehidupan baru yang menerapkan standar protokol kesehatan ketat. Kearifan lokal yang dahulu cenderung tersisihkan, kini kembali berkembang, seperti Sagilik Saguluk, Briuk Sapanggul, Tri Hita Karana, Desa Kala dan Patra.
\end{abstract}

Kata Kunci: Pandemi Covid-19, Tatanan Kebiasaan Baru, Psikologi Pariwisata 


\section{PENDAHULUAN}

Pandemi yang ditimbulkan oleh virus corona semenjak akhir tahun 2019 telah membuat kehidupan manusia mengalami perubahan besar. Pandemi juga mengakibatkan terpuruknya tatanan perekonomian, hancurnya industri pariwisata dan perhotelan, tatanan kehidupan bermasyarakat yang berubah, gangguan sistem pendidikan, berubahnya norma sosial, dan berbagai hal lain. Sebanyak 1.033 restoran dan hotel di Indonesia yang tutup secara permanen akibat dampak Covid-19 yang berkepanjangan. Data ini dengan berdasar pada hasil riset yang dilakukan pada 4.469 responden dari 9.000 restoran dan hotel di seluruh Indonesia pada bulan September 2020. Semenjak Oktober 2020 hingga kini, sekitar 125 hingga 150 restoran yang tutup per bulannya. Sutrisno Iwantono, Ketua Badan Pimpinan PHRI, menjelaskan hal ini kepada Antara.com (Jum'at, 5 Februari 2021).

Penerapan berbagai upaya mengatasi Covid-19 juga memperparah kondisi usaha restoran dan hotel. Pembatasan jam operasional, penerapan karantina wilayah (lockdown) yang berlaku setiap akhir pekan atau dalam periode waktu tertentu, berdampak pada semakin terpuruknya usaha jasa dan akomodasi yang ada. Hambatan yang telah ada sebelumnya, membuat berbagai pihak harus bersatu padu menerapkan strategi pemulihan perkembangan sektor pariwisata. Salah satu upaya yang bisa diterapkan adalah pariwisata yang berbasis kemasyarakatan dengan melibatkan masyarakat.

Berbagai pandangan yang pro dan kontra terkait hal ini selalu berkembang di tengah masyarakat. Terakhir adalah kebijakan Pemberlakuan Pembatasan Kegiatan Masyarakat (PPKM) Darurat tanggal 3-20 Juli 2021, melalui Instruksi Mendagri No. 5 tahun 2021, tentang PPKM Darurat Covid-19 di Jawa dan Bali. InMendagri ini kemudian direvisi, PPKM Darurat Covid-19 diperpanjang menjadi enam minggu hingga 2 Agustus 2021, dan diperpanjang kembali hingga 9 Agustus 2021.

Perkembangan Pandemi Covid-19 di tanah air ini mempengaruhi situasi dan kondisi mental masyarakat, mempengaruhi kinerja karyawan perhotelan, mempengaruhi kebijakan yang dikeluarkan pemerintah dan para pemangku kepentingan lainnya. Hal ini mendorong lahirnya berbagai penelitian dari berbagai sudut pandang terhadap pandemi Covid-19. Salah satunya adalah pandemi dalam perspektif psikologi pariwisata. Tulisan ini mencoba membahas perkembangan pandemi Covid-19 yang terjadi di Bali, yang membuat masyarakat mengubah kebiasaan hidup dalam suatu tatanan kebiasaan baru dari perspektif psikologi pariwisata.

\section{METODE PENELITIAN}

Penelitian ini menggunakan metode kualitatif. Menurut Muhadjir (1992: 24) penelitian kualitatif adalah penelitian yang menghasilkan deskripsi berupa kata-kata tertulis atau lisan dari orang dan pelaku yang dapat diamati berdasarkan fenomena pendekatan holistik (utuh). Penelitian ini menggunakan pendekatan psikologi pariwisata yang membantu peneliti mengungkap fenomena psikologis yang terjadi dan berkaitan dengan penelitian ini.

Metode pengumpulan data dalam penelitian ini adalah studi pustaka. Paramita (2020) menjelaskan bahwa penelitian yang menggunakan metode pengumpulan data berupa studi pustaka menggunakan data sekunder. Data sekunder merupakan data atau informasi yang diambil dari buku, internet, arsip, dan lain sebagainya yang menunjang suatu penelitian. Penelitian ini melakukan pengumpulan data sekunder terkait psikologi pariwisata dan tatanan kebiasaan baru. Tinjauan pustaka yang diperoleh merupakan ringkasan dan sinopsis yang merupakan hasil dari bidang riset terdahulu yang 
memungkinkan karya tulis ini sebagai dasar teori penelitian berikutnya.

\section{HASIL DAN PEMBAHASAN}

\subsection{Psikologi Pariwisata}

Istilah psikologi bukan merupakan hal yang baru lagi di tengah masyarakat. Berbagai ruang pertemuan, diskusi dan konsultasi sering mengupas topik psikologi. Hal ini membuat psikologi merupakan suatu kebutuhan dalam menghantar pemahaman masyarakat terkait berbagai situasi kehidupan. Menurut Dalino dalam Paranoan (2003), psikologi merupakan ilmu yang mempelajari mental manusia dan dibutuhkan dalam upaya mencapai kesejahteraan hidup manusia itu sendiri. Seseorang yang memahami psikologi dapat membantu dirinya dan orang lain mengatasi gangguan psikologi. Hal ini menyebabkan ilmu psikologi kerap dimanfaatkan untuk menemukan solusi dari permasalahan hidup. Dengan demikian, penting bagi umat manusia memahami lebih mendalam psikologi terkait kesehatan mental.

Konsep dan definisi pariwisata bermanfaat dalam menelaah situasi yang terjadi global karena konsep dan definisi psikologi pariwisata mampu menyamakan persepsi masyarakat yang terlibat dengan kondisi pariwisata. Utama (2015) menjelaskan bahwa psikologi pariwisata membantu menyamakan persepsi terkait pemanfaatan maksimal berbagai aspek psikologis dari pihak yang terlibat, baik masyarakat, wisatawan, pengusaha dan pekerja pariwisata, juga pemerintah.

Bakker \& Demerouti (2008) mengembangkan model psikologis mengenai tuntutan pekerjaan dan sumber daya yang terlibat dalam kerja. Menurut Bakker dan Demerouti, dimensi pada Job Demand mencakup tekanan pekerjaan yang tinggi (work pressure), kondisi emosi yang terkait dengan pekerjaan (emotional demand), kerumitan dalam pekerjaan (hassle), konflik peran (role conflict), dan kondisi pekerjaan yang membutuhkan pemikiran yang kompleks (cognitive demand). Dimensi pada Job Resources terdiri dari otonomi dalam bekerja (Autonomy), dukungan sosial (Social Support), umpan balik (Feedback), kesempatan untuk berkembang (Opportunities for development), dan bimbingan dari atasan (Coaching). Penelitian Baker dan Demerouti ini menjelaskan tentang kondisi kepribadian seseorang. Mereka menjelaskan aspek-aspek psikologis yang terkait dengan job demand dan job resources. Penelitiannya memperlihatkan bahwa kondisi psikologi memiliki peranan penting dalam kualitas kerja.

Penelitian Anugrah (2017) menjelaskan bahwa job demand dan job resources berpengaruh terhadap kepuasan kerja pegawai Disbudpar Provinsi NTB. Anugrah menggunakan alat ukur Job Satisfaction Survey dari Spector, dan Job Demands - Resources dari Bakker. Penelitiannya membuktikan bahwa terpenuhinya job demand dan tersedianya job resources berpengaruh signifikan terhadap tingkat kepuasan kerja karyawan. Herawati dalam Renanita (2016) menjelaskan bahwa pemahaman dan implementasi Psikologi Konsumen sebagai strategi pemasaran industri wisata yang terbukti efektif sekaligus efisien. Menurut Herawati dalam Renanita (2016) pemahaman aspek psikologi membantu pengembangan strategi pemasaran industri wisata yang tepat dan berkelanjutan pada suatu daerah. Ayunita (2017) menjelaskan bahwa pemahaman dan penerapan psikologi pariwisata bermanfaat dalam pengembangan pariwisata kreatif, contohnya wisata petualang, dan memiliki implikasi yang signifikan bagi pertumbuhan pariwisata dan ekonomi.

Uraian di atas menjelaskan bahwa Psikologi Pariwisata memberikan pemahaman aspek-aspek psikologis berbagai pihak yang terlibat dalam pengembangan pariwisata secara berkelanjutan. Hal ini penting karena karakteristik pariwisata yang berbeda dan unik dari suatu destinasi dengan 
destinasi lain, masyarakat, para pekerja yang terlibat, dan wisatawan yang datang, situasi perekonomian, sosial, kondisi alam, membutuhkan penanganan yang berbeda pula. Pemahaman yang baik dapat membantu penyusunan strategi yang bagus pula, sehingga lebih tepat dalam penetapan upaya pengembangan sustainability tourism.

\subsection{Tatanan Kebiasaan Baru}

New normal merupakan suatu bentuk adaptasi pola aktivitas baru yang dilakukan pada masa merebaknya pandemi Covid-19 (Adi Pratama, 2020). New Normal dapat juga diartikan situasi yang diterapkan dalam upaya memberikan jaminan atas rasa aman (security at work) dan dukungan dari para rekan kerja (co-worker support) selama bekerja dii Provinsi Bali. Tatanan Kehidupan Baru ini dimulai pada tanggal 9 Juli 2020, ditandai dengan kegiatan pelepasan tur mobil klasik oleh Wakil Gubernur Bali, Tjokorda Oka Artha Ardana Sukawati, dengan rute DenpasarKarangasem-Buleleng-Tabanan. New normal merupakan aktivitas dimana manusia beradaptasi dengan beraktivitas dan bekerja dengan cara mengurangi kontak fisik dengan orang lain, menghindari kerumunan, bekerja dan bersekolah dari rumah. Wiku Adisasmita, Ketua Tim Pakar Satgas Covid Indonesia menjelaskan hal tersebut dalam Krisdayanthi (2020).

Ahmad Yurianto dalam Putsanra (2020) mengemukakan bahwa produktivitas harus tetap terjaga oleh masyarakat di tengah situasi pandemi Covid-19. Berbagai macam upaya dilakukan, termasuk pula dengan melakukan berbagai perubahan atau adaptasi kebiasaan yang sebelumnya sudah ada. New normal (tatanan kehidupan baru) merupakan pola tatanan, kebiasaan atau perilaku yang baru berbasis adaptasi budaya perilaku hidup bersih dan sehat dengan cara rutin cuci tangan pakai sabun, pakai masker saat berada di luar rumah, selalu jaga jarak aman dengan orang lain, menghindari kerumunan.

Penelitian ini didorong oleh adanya pengaruh pandemi terhadap perkembangan kondisi psikologis pariwisata berdasar penelitian Pratiwi, Rama, Sulistyanti (2021) terkait Building the trust for the tourism destination resiliency in new normal society (the role of wellness tourism system), Suprihatin (2020) tentang analisis perilaku konsumen wisatawan era pandemi Covid-19 (Studi kasus pariwisata di Nusa Tenggara Barat), dan Megaartha (2021) tentang optimalisasi dan adaptasi kultur perekonomian baru di era pandemi Covid-19 guna menggerakkan roda perekonomian khususnya pada usaha penginapan. Selain itu, penelitian lain yang mendasari adalah penelitian Simanjuntak \& Fitriana (2020) tentang Culture shock, adaptation and self concept of tourism human resources in welcoming the new normal era serta penelitian yang dilakukan oleh Utama (2011) terkait dimensi ekonomi pariwisata kajian dampak ekonomi dan keunggulan pariwisata kabupaten/kota di Provinsi Bali.

Pandemi Covid-19 membuat perubahan besar dalam kehidupan masyarakat. Berubahnya struktur dan sistem kehidupan menjadi suatu pola tatanan kebiasaan baru dengan berbagai kebijakan yang dikeluarkan pemerintah. Hal lain yang juga dilakukan pemerintah adalah melakukan sertifikasi penerapan standar protokol kesehatan bagi hotel dan restoran serta destinasi wisata. Ini memperlihatkan tanda keseriusan dan kesiapan melaksanakan Adaptasi Kebiasaan Baru. Tribun menjelaskan bahwa tercatat sudah 1.837 tempat usaha di Bali yang memiliki sertifikasi terkait standar protokol kesehatan di masa pandemi Covid-19 ini.

\subsection{Pembahasan}

Situasi dan kondisi drastis yang dihasilkan pandemi Covid-19 juga berdampak pada situasi dan kondisi pariwisata di Bali. Penelitian ini 
menemukan bahwa hotel dan restoran di Bali juga menjadi bagian dari 1.033 hotel dan restoran yang telah tutup di seluruh Indonesia. Data ini bertambah 125-130 hotel dan restoran yang tutup setiap bulannya semenjak Oktober 2020.

Pandemi Covid-19 memberi dampak psikologi berbacam-macam dalam diri masyarakat dan wisatawan. Dampak psikologi yang muncul bisa gangguan pikiran, kecemasan berkepanjangan, tuntutan wisatawan atas jaminan kesehatan dan kebersihan lingkungan yang dikunjungi, dan munculnya jejaring sosial sebagai bentuk kepedulian atas situasi pandemi Covid-19. Dalam rangka menangani pandemi Covid-19, pemerintah mengeluarkan berbagai peraturan dan kebijakan seperti vaksinasi, standarisasi sertifikasi badan usaha dan jasa pariwisata serta perhotelan. Hal ini juga bertujuan memberikan rasa aman, meningkatkan kualitas hidup masyarakat, menjaga kebersihan dan kesehatan lingkungan, serta pengendalian pandemi Covid-19.

Istilah new normal yang berkembang, bukan merupakan istilah baru. Miller dan Benjamin dalam Diwyarthi (2021) menjelaskan new normal sebagai dampak krisis ekonomi dunia 20072008, yang kemudian menjadi popular untuk menjelaskan dampak resesi global dan wabah pandemi Covid-19. Dalam new normal, hal-hal yang terkesan tidak normal atau belum menjadi kebiasaan kenormalan baru akibat situasi-situasi tersebut.

Penerapan berbagai upaya mengatasi Covid-19 juga memperparah kondisi usaha restoran dan hotel. Pembatasan jam operasional, penerapan karantina wilayah (lockdown) yang berlaku setiap akhir pekan atau dalam periode waktu tertentu, berdampak pada semakin terpuruknya usaha jasa dan akomodasi yang ada. Hambatan yang telah ada sebelumnya, membuat berbagai pihak harus bersatu padu menerapkan strategi pemulihan perkembangan sektor pariwisata. Salah satu upaya yang bisa diterapkan adalah pariwisata yang berbasis kemasyarakatan dengan melibatkan masyarakat.

Adi Pratama dalam Diwyarthi (2021) menjelaskan bahwa manusia dengan berbagai aktivitas kehidupan merupakan sebuah kegiatan yang akan senantiasa bergulir tiada henti, karena orang selalu bergerak, selalu beraktivitas, dalam mencapai kepuasan. Pemahaman terhadap konsep ini membuat kita bisa menerapkan berbagai upaya terbaik terhadap standar kehidupan yang ada. Salah satunya dengan sustainability society development, melibatkan masyarakat setempat untuk senantiasa membangun jejaring pariwisata (connectivity), menggunakan daya kreativitas (creativity) dalam menggali berbagai inovasi (inovation), membangun metode digital (digitalisasi) dan penerapan teknologi (technology) tanpa mengabaikan sisi manusiawi dan empati (emphaty), serta melibatkan berbagai komponen masyarakat untuk bersatu demi yang terbaik bagi masyarakat itu sendiri (society).

Hal ini menjelaskan bahwa perkembangan masyarakat secara berkelanjutan membutuhkan keterlibatan berbagai pihak. Mau tidak mau, suka atau tidak, setiap pihak harus bisa bersama, terbuka dalam berbagai perubahan yang akan selalu terjadi. Contohnya, perkembangan pariwisata di Bali dipengaruhi perkembangan pariwisata di Jawa dan di daerah lain di nusantara, bahkan di dunia. Penerapan peraturan yang berlaku di Jakarta dalam upaya penanganan pandemi Covid-19 akan berdampak pada situasi pariwisata yang berjalan di daerah lain di nusantara, juga daerah lainnya.

Manajemen hotel di masa pandemi Covid-19 berusaha mendukung anjuran pemerintah untuk menjalani physical distancing dan Work From Home (WFH). Pemerintah secara bertahap menerapkan pola hidup masyarakat dalam suatu bentuk adaptasi kebiasaan baru, sesuai dengan standardisasi hidup disiplin mencakup 5 M (memakai masker, mencuci tangan, menjaga jarak, 
menghindari kerumunan, mengurangi mobilitas), Kementerian Pariwisata dan Ekonomi Kreatif (Kemparekraf) gencar melakukan sosialisasi protokol kesehatan yang dikemas dalam program cleanliness, health, safety dan environment (CHSE).

Protokol kesehatan tersebut diterapkan karena upaya pemulihan kondisi pariwisata sangat ditentukan oleh tingkat kepercayaan. Hal ini membutuhkan kerjasama masyarakat luas yang disiplin dalam menerapkan protokol kesehatan. Protokol kesehatan mengacu pada 3 aspek utama, yakni bersih, sehat dan aman lingkungan dimana pariwisata berada. Pemberlakuan protokol kesehatan diharapkan dapat meningkatkan standar kebersihan, kesehatan dan keamanan pada sektor pariwisata. Hal ini membantu meningkatkan kepercayaan masyarakat dalam melaksanakan aktivitas sehari-hari, juga wisatawan yang datang berkunjung ke tempat wisata dan menginap di hotel yang ada, serta mengurangi resiko penyebaran virus corona.

Hal ini sesuai dengan pendapat Diwyarthi (2018) yang menjelaskan bahwa kondisi psikologis yang sehat membantu mencapai kepuasan dalam bekerja. Adanya peraturan ketenagakerjaan menjamin kesehatan mental karyawan. Kesehatan mental karyawan dapat berupa perlindungan terhadap keselamatan dan keamanan selama bekerja, motivasi yang diberikan oleh atasan dan rekan kerja lain, kondisi psikologis karyawan juga berpengaruh terhadap kondisi psikologi pariwisata. Perkembangan yang terjadi membutuhkan suatu tatanan penanganan dengan standar norma baru, dan dengan melibatkan berbagai komponen, baik pemerintah, masyarakat, pengusaha, juga wisatawan. Salah satu upaya yang dilakukan adalah dengan menggali dan menerapkan kebijakan lokal yang sesuai dengan adat istiadat, tradisi, maupun kondisi masyarakat setempat. Kebijakan lokal yang bersumber dari warisan luhur semenjak nenek moyang, membuat berbagai komponen masyarakat beserta pemerintah desa merencanakan beragam paket wisata sebagai komoditas andalan bagi para wisatawan di era pandemi.

Salah satu yang diterapkan adalah adanya aktivitas keseharian masyarakat di Bali, yakni Desa Kala Patra dan Tri Hita Karana. Aktivitas ini dikemas secara menarik yang kemudian ditawarkan menjadi beragam paket wisata spiritual, sesuai dengan protokol kesehatan. Hal ini dilakukan dalam rangka menyikapi perkembangan pariwisata di era tatanan kebiasaan baru (New Normal Era). Perilaku dan tindakan yang mendorong kebudayaan Bali lebih dinamis dan adaptif dalam menghadapi nilai luar, juga hal-hal baru. Contohnya, kapasitas jumlah pengunjung dibatasi, dengan pengecekan kondisi kesehatan sebelum penonton masuk ke dalam area pertunjukan. Seniman dan orang yang terlibat dalam kegiatan pariwisata, juga sudah melakukan pengecekan kondisi kesehatan, mendapatkan vaksin anti virus, dan melengkapi diri dengan alat pelindung diri (APD), dan pembatasan orang yang terlibat serta waktu kegiatan. Ini dilakukan dengan melibatkan berbagai komponen pariwisata yang ada di tengah masyarakat, seperti wisatawan yang datang berkunjung dalam kondisi sehat dengan pengawasan bersama, keterlibatan komponen masyarakat seperti pecalang dan sekeha teruna teruni, ibu-ibu PKK setempat, manajemen hotel dan villa serta restoran sudah mendapatkan sertifikasi Cleanlines, Healthy, Safety and Environment (CHSE).

Hal ini sesuai dengan hasil penelitian Diwyarthi (2020) terkait Kearifan Lokal Masyarakat Bali dalam Menghadapi Pandemi Covid-19, bahwa masyarakat memiliki warisan luhur budaya yang dipergunakan dalam menyikapi situasi pandemi. Contohnya Sagilik Saguluk, Salunglung Sabayantaka, Briuk Sapanggul, Tri Hita Karana, Desa Kala 
Diwyarthi

dan Patra. Ini membantu mengembangkan sifat positif kondisi Psikologi Pariwisata di tengan pandemiCovid-19, dimana masyarakat saling memotivasi satu sama lain, membantu dan mengingatkan bila ada yang melanggar protokol kesehatan, mengaktifkan kegiatan seni budaya, dan melibatkan ibu rumah tangga juga pemuda dalam berbagai aktivitas desa.

\section{KESIMPULAN}

Pariwisata mengalami perubahan besar terkait situasi Pandemi Covid-19. Penelitian ini membuktikan terdapat berbagai perspektif dan pandangan terhadap perkembangan pariwisata. Psikologi Pariwisata membantu pemetaan situasi pariwisata dalam era tatanan kehidupan baru. Situasi yang terjadi dalam masa pandemi Covid-19 sangat relevan dikupas berdasar metode ilmiah modern yang terkandung pada Psikologi Pariwisata.

Perspektif psikologi pariwisata memperlihatkan bahwa meski Pandemi Covid-19 telah menghancurkan kondisi pariwisata secara global dan mengakibatkan gangguan psikologis, namun berbagai upaya meningkatkan kepercayaan para pelaku dan pasar yang ada terus ditingkatkan. Pandemi Covid19 telah membuat perkembangan dunia pariwisata disesuaikan dengan standar protokol kesehatan, juga situasi dan kondisi masyarakat yang terlibat, baik para pekerja, wisatawan yang datang, dan masyarakat sekitar dimana pariwisata berada. Dengan demikian, kondisi psikologi pariwisata dapat memberikan jaminan keamanan, kesehatan dan keberlangsungan pariwisata itu sendiri.

Psikologi Pariwisata membantu dunia pengetahuan memahami dengan tepat karakter perkembangan masyarakat, dan pendekatan yang tepat dalam menggerakkan masyarakat secara bersama dan terus menerus (sustainability society development). Hanya dengan kemampuan menjalin kerjasama dalam berbagai komponen yang ada di tengah masyarakat, pemerintah, dan lingkungan yang ada, maka pembangunan masyarakat dapat berjalan dengan baik, dalam suatu era tatanan kehidupan baru, pada masa pandemi Covid-19

\section{DAFTAR PUSTAKA}

Krisdayanthi, A. (2020). New Normal Pariwisata Bali di Masa Pandemi pada DTW Tanah Lot. Pariwisata Budaya: Jurnal Ilmiah Pariwisata Agama dan Budaya, 5(2), 49-56. DOI: http://dx.doi.org/10.25078/pba. v3i2.

Megaartha. (2021). Optimalisasi dan Adaptasi Kultur Perekonomian Baru di Era Pandemi Covid-19 Guna Menggerakkan Roda Perekonomian Khususnya pada Usaha Penginapan. Jurnal Acytia Ardana.

Paramita, IBG. \& Purnama, G. (2020). New Normal bagi Pariwisata Bali di Masa Pandemi Covid-19. Pariwisata Budaya: Jurnal Ilmiah Pariwisata Agama dan Budaya, 5(2), 57-65. DOI: http://dx.doi.org/10.25078/pba. v3i2.

Pratiwi, R., Rama, Sulistyanti, N. (2021). Building The Trust for The Tourism Destination Resiliency in New Normal Society (The Role of Wellness Tourism System). Jurnal IKRA-ITH Humaniora, 5(1).

Dwiyarthi N. D. M. S (2018). Implementasi Peraturan Ketenagakerjaan pada Hotel Berbintang di Bali. Pariwisata Budaya: Jurnal Ilmiah Pariwisata Agama dan Budaya, 3(2), 42-50. DOI: http://dx.doi.org/10.25078/pba. v3i2.

Simanjuntak \& Fitriana, R. (2020). Culture Shock, Adaptation and Self Concept of Tourism Human Resources in Welcoming The New Normal Era. Jurnal Society.

Suprihatin, W. (2020). Analisis Perilaku Konsumen Wisatawan Era Pandemic Covid-19 (Studi Kasus Pariwisata di Nusa Tenggara Barat). Jurnal Bestari NTB, 1(1) 
Diwyarthi

Adi P, W. (2020). Manajemen Pariwisata. Denpasar

Anugrah, A. B. (2017). Pengaruh Job Demands dan Job Resources terhadap Kepuasan Kerja Pegawai Disbudpar NTB. Surabaya: Unair.

Ayunita, CD. (2017). Studi Pustaka Wisata Petualang di Indonesia. Skripsi tidak diterbitkan. Bandung: Unpad.

Bakker, A.B. \& Demerouti. E. (2008). Towards a Model of Work Engagement. The Journal of Career Development International.

Herlandy, P.B., \& Novalia, M. (2019). Penerapan E-Learning pada Pembelajaran Komunikasi

Parang, M. (2003). Peranan Psikologi terhadap Perkembangan Masyarakat Pasca Modernisasi. Makasar: Jaffray.

Renanita T. (2016). Memahami Psikologi Konsumen sebagai Strategi Pemasaran Industri Wisata

Dwiyarthi N. D. M. S (2021). Tourism Management: Principles, Challenges and Opportunities. Jogja: Diandra Kreatif.

Dwiyarthi N. D. M. S (2021). Psikologi Sosial. Jogja: Widina.

Utama, IGBR. (2011). Dimensi Ekonomi Pariwisata Kajian Dampak Ekonomi dan Keunggulan Pariwisata Kabupaten/Kota di Provinsi Bali. Denpasar: Univ. Udayana.

Utama, IGBR. (2015). Pengantar Industri Pariwisata. Denpasar: Undhira

Putsanra, D. V. (2020). Arti new Normal Indonesia: Tatanan Baru Beradaptasi dengan Covid-19

https://tirto.id/arti-new-normalindonesia-tatanan-baru-beradaptasidengan-covid-19-fDB3.

Ramadhian, N. (2021). 1.871 Usaha Pariwisata di Bali Sudah Dapat Sertifikat CHSE. travel.kompas.com. Retrieved from

https://travel.kompas.com/read/2021/ 07/27/132603327/1871-usahapariwisata-di-bali-sudah-dapatsertifikat-chs 